\title{
Length-Weight Relationship and Condition Factor of Schizothorax plagiostomus found in River Jhelum from Kashmir Valley
}

\author{
Zubair Ahmad Sheikh and Imtiaz Ahmed* \\ Fish Nutrition Research Laboratory, Department of Zoology, University of Kashmir, \\ Hazratbal, Srinagar - 190006, Jammu and Kashmir, India; imtiazamu1@yahoo.com
}

\begin{abstract}
Length weight relationship is important in describing several biological aspects of fish species found under cultured and natural condition. Length weight relationship provides information about whether somatic growth was isometric or allometric. While condition factor provide information about the well being fish. In the present study the individuals of Schizothorax plagiostomus were collected from river Jhelum from different locations for the determination of length weight relationship and condition factor during the period of 2014-2016. Length weight relationship was computed using the equation $\mathrm{W}=\mathrm{aL}^{\mathrm{b}}$, which was further transformed into $\log W=\operatorname{Loga}+$ bLog L. Results showed that the value of $\mathrm{b}$ in length weight relationship of male S. plagiostomus ranged from 2.316-2.965, while in female fishes the value of b ranged from 2.01-3.66. The results clearly show allometric type of growth in male and isometric type of growth in females. The regression coefficient between males and female did not shows any significant difference, $(p>0.05)$ whereas significant difference $(P<0.01)$ could be noticed between males and between females $(p<0.01)$. However, condition factor (K) of S. plagiostomus fluctuates between $0.82-1.58$ in male and between 0.870-1.31in female, indicating the robustness of the fish inhabiting in river Jhelum.
\end{abstract}

Keywords: Condition Factor, Jhelum, Length Weight, Schizothorax plagiostomus

\section{Introduction}

Length-weight Relationship (LWR) studies of fishes is considered as an important tool for understanding of fish health status. Length-weight Relationship of fishes is also important in fisheries and fish biology as its allow the estimation of the average weight of the fish of a given length group by establishing a mathematical relation between them ${ }^{6}$. Length-weight Relationships have broadly been used for the conversion of growth-in-length equations to growth-in-weight for use in stock assessment models in order to estimate the stock assessment, relate the life histories of certain species and other changing aspects of fish population ${ }^{2,32,48,31,51}$ Nile et al., 2013;. Like any other morphometric characters, the LWR can be used as a character for the differentiation of taxonomic units and the relationship changes with the various developmental events. In addition, the Length-weight Relationship indicates the degrees of stabilization of taxonomic characters in fish species and very useful in the management and exploitation of fish populations ${ }^{39}$. Growth of fish, usually indicated through increase in length and weight which is considered as the most appropriate characteristic to determine the population analysis at a particular time ${ }^{21}$. Now a days study of Length-weight Relationships (LWRs) of threatened fish species are the most important biological parameters to provide information about the growth and condition of fish species as well as entire fish community and are highly significant for management and conservation of natural populations ${ }^{43,33}$. Fulton's condition factor (k) is extensively used in fisheries and fish biology studies. This factor refers to the well-being of a certain species and its degree of fatness which depends on the weight of the fish ${ }^{38,13}$. Condition factor reflects the variations by interaction among feeding conditions, parasitic infection and physiological factors and recent physical and biological circumstances ${ }^{24,5,49,28}$. The study of condition assumes that heavier organisms of a given length are in better physical state, therefore, condition indices are used in fishery sciences as indicators of the length-weight-relationship of a population. Condition factor also helps to reflect the feeding conditions of the species.

*Author for correspondence 


\section{Material and Method}

Our study estimates LWRs of indigenous cold water species Schizothorax plagiostomus belonging to family Cyprinidae and order Cypriniformes. The samples of S. plagiostomus were collected from 2014-2016 from locations of river Jhelum of Kashmir valley with the help of fisherman. After collection, the samples were brought into wet laboratory Department of Zoology, University of Kashmir and the required measurement of length and weight were taken by using digital caliper and digital weighing balance, respectively. The total length of fish was measured to its nearest $0.01 \mathrm{~cm}$ and total body weight was measured to its near $0.01 \mathrm{~g}$. The total length of fish was taken from the tip of snout to the extended tip of the caudal fin and the relationship was analyzed by measuring length and weight of fish specimen collected from study area. The statistical relationship between these parameters of fishes was analyzed with the help of algometric equation by Forese (2006).

$\mathrm{W}=\mathrm{aL}$

Where $\mathrm{W}=$ Total weight $(\mathrm{g})$.

$\mathrm{L}=$ length of fish $(\mathrm{cm})$.

$\mathrm{a}=$ Initial growth coefficient.

$\mathrm{B}=$ Slope or the growth coefficient.

The value of constants ' $a$ ' and 'b' was estimated by linear regression after logarithimic transformation of weight and length data by using formula:

$$
\log W=\log a+b \log L
$$

\subsection{Determination of Condition Factor}

Condition factor is used for comparing the condition, fatness or well-being of fish, based on the assumption that heavier fish of a given length are in better condition. The coefficient of condition ' $\mathrm{K}$ ' was calculated using ${ }^{15}$ equation:

$$
\mathrm{K}=\mathrm{W} / \mathrm{L}^{3} \times 100
$$

Where, $\mathrm{W}=$ weight $(\mathrm{g}), \mathrm{L}=$ length $(\mathrm{cm})$ and 100 is a factor to bring the value of $\mathrm{K}$ near unity.

\section{Results}

The Length-weight Relationship of S. plagiostomus representing male, female and pooled (both sexes) are presented in Figure 1, Figure 2 and Figure 3, respectively. The equations thus derived in respect of Length-weight Relationship are as follows:

Females: $\log \mathrm{W}=1.764+2.895 \log \mathrm{L}$

Males: $\log \mathrm{W}=1.690+2.736 \log \mathrm{L}$

Combined: $\log \mathrm{W}=1.656+2.7145 \log \mathrm{L}$

In the present study increase in ' $\mathrm{b}$ ' value in male fish showed deviation from cube law throughout the annual period as negative allometric growth was observed throughout the annual period i:e $b<3$. The growth coefficient was minimum in March (2.315) and maximum was observed in July (2.965). The coefficient of determination ' $\mathrm{r}^{2}$ ' fluctuates from 0.90 (January) to 0.990 in (June) as shown in Table 1. In case of females the value of ' $b$ ' also indicated deviation from cube law throughout annual period except, May, July and August were value of $b>3$. However, this was to be attributed to the fact that during these months presence of high food availability and favorable environmental temperature, as compared to rest of months. This has led to almost ideal growth pattern of the fish. During annual period the female $S$. plagiostomus, shows coefficient of determination oscillates between (July) 0.901 to 0.975 in October (Table 2). The month wise Fulton's condition factor, of male, S. plagiostomus ranged from 0.82 to 1.583 and it was observed highest in the month of June followed in the month of July and December, respectively while lowest value was recorded in the month of September followed by January. Whereas in case of female, S. plagiostomus the condition factor values are in the range of 0.870-1.31 with highest condition factor was recorded in the month of June followed by July, October and lowest value was recorded in the month of April followed March and January, respectively (Table 3 ). The variation of condition factor in both male and female Schizothorax plagiostomus is depicted in Figure 4.

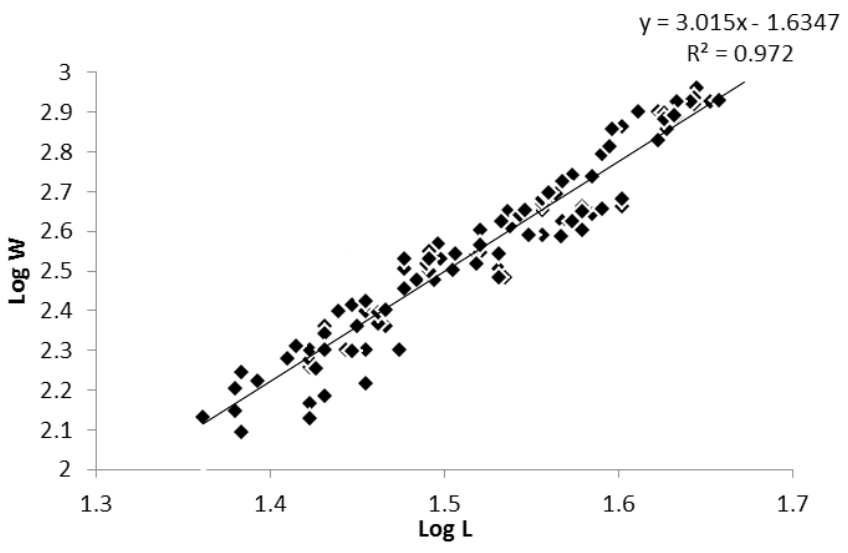

Figure 1. Depicts Length-Weight Relationship of Schizothorax plagiostomus (Male).

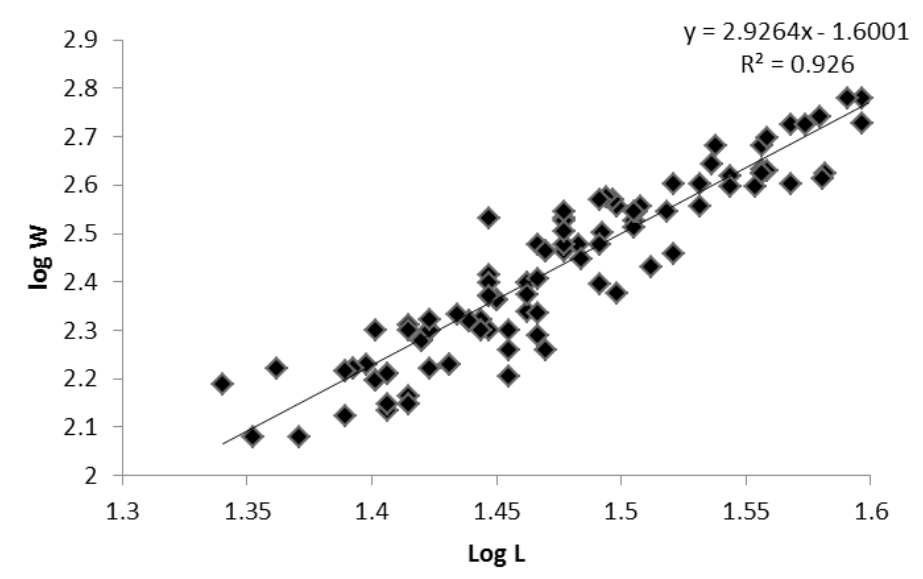

Figure 2. Depicts Length-Weight Relationship of Schizothorax plagiostomus (Female). 


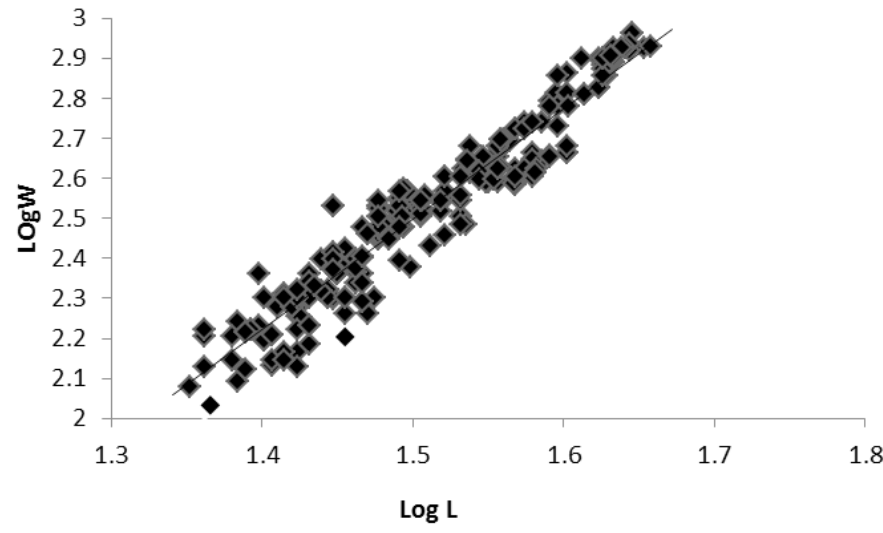

Figure 3. Depicts Length-Weight Relationship of S. plagiostomus Combined.

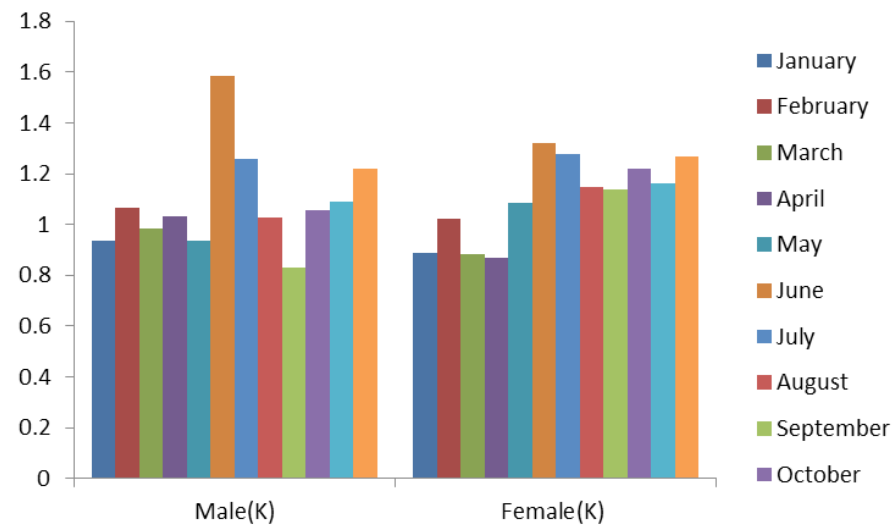

Figure 4. Depicts month wise condition factor of both male and female S. plagiostomus

Table 1. Month wise Length-Weight Relationships of S. plagiostomus (Males) in river Jhelum from Kashmir valley

\begin{tabular}{|c|c|c|c|c|c|c|c|c|}
\hline \multirow[t]{2}{*}{ Months } & \multirow[t]{2}{*}{$\mathbf{N}$} & \multicolumn{2}{|c|}{$\begin{array}{l}\text { Total Length } \\
(\mathrm{cm})\end{array}$} & \multicolumn{2}{|c|}{ Total Weight (gm) } & \multicolumn{2}{|c|}{$\begin{array}{l}\text { Regression Parameters } \\
\qquad \mathrm{W}=\mathrm{aL}^{\mathrm{b}}\end{array}$} & \multirow[t]{2}{*}{$\mathbf{r}^{2}$} \\
\hline & & Min. & Max. & Min. & Max. & a & $\mathbf{b}$ & \\
\hline January & 12 & 30 & 37 & 295 & 323 & 1.789 & 2.564 & 0.905 \\
\hline February & 12 & 26 & 31 & 210 & 310 & 1.876 & 2.435 & 0.935 \\
\hline March & 12 & 28 & 36 & 290 & 360 & 1.764 & 2.315 & 0.956 \\
\hline April & 12 & 24 & 32 & 230 & 310 & 1.564 & 2.316 & 0.946 \\
\hline May & 12 & 30 & 38 & 300 & 375 & 1.734 & 2.356 & 0.976 \\
\hline June & 12 & 23 & 29 & 240 & 280 & 1.489 & 2.563 & 0.990 \\
\hline July & 12 & 27 & 39 & 290 & 370 & 2.670 & 2.965 & 0.908 \\
\hline August & 12 & 29 & 34 & 280 & 340 & 1.785 & 2.435 & 0.911 \\
\hline September & 12 & 31 & 36 & 285 & 325 & 1.297 & 2.927 & 0.959 \\
\hline October & 12 & 29 & 37 & 295 & 310 & 1.786 & 2.433 & 0.921 \\
\hline November & 12 & 31 & 35 & 295 & 335 & 1.234 & 2.315 & 0.901 \\
\hline December & 12 & 30 & 35 & 288 & 310 & 1.456 & 2.198 & 0.965 \\
\hline Mean \pm SD & & $28.16 \pm 2.65$ & $34.91 \pm 2.96$ & $274.83 \pm 30.21$ & $329 \pm 28.30$ & $1.70 \pm 0.36$ & $2.48 \pm 0.23$ & $0.93 \pm 0.03$ \\
\hline
\end{tabular}

Table 2. Month wise of length-Weight relation of S. plagiostomus (Female) in river Jhelum from Kashmir valley

\begin{tabular}{|c|c|c|c|c|c|c|c|c|}
\hline \multirow[t]{2}{*}{ Months } & \multirow[t]{2}{*}{$\mathbf{N}$} & \multicolumn{2}{|c|}{ Total Length $\mathrm{cm}$} & \multicolumn{2}{|c|}{ Total Weight (gm) } & \multicolumn{2}{|c|}{$\begin{array}{c}\text { Regression Parameters } \\
\qquad \mathbf{W}=\mathrm{aL}^{\mathbf{b}}\end{array}$} & \multirow[t]{2}{*}{$\mathbf{r}^{2}$} \\
\hline & & Min. & Max. & Min. & $\operatorname{Max}$ & $\mathbf{a}$ & b & \\
\hline January & 12 & 32 & 37 & 326 & 360 & 1.573 & 2.897 & 0.936 \\
\hline February & 12 & 28 & 35 & 272 & 415 & 1.786 & 2.887 & 0.949 \\
\hline
\end{tabular}




\begin{tabular}{|c|c|c|c|c|c|c|c|c|}
\hline \multirow[t]{2}{*}{ Months } & \multirow[t]{2}{*}{$\mathbf{N}$} & \multicolumn{2}{|c|}{ Total Length $\mathrm{cm}$} & \multicolumn{2}{|c|}{ Total Weight (gm) } & \multicolumn{2}{|c|}{$\begin{array}{c}\text { Regression Parameters } \\
\qquad \mathrm{W}=\mathrm{aL}^{\mathrm{b}}\end{array}$} & \multirow[t]{2}{*}{$\mathbf{r}^{2}$} \\
\hline & & Min. & Max. & Min. & Max & $\mathbf{a}$ & b & \\
\hline March & 12 & 31 & 38 & 310 & 345 & 1.674 & 2.967 & 0.917 \\
\hline April & 12 & 32 & 36 & 320 & 365 & 1.789 & 2.980 & 0.938 \\
\hline May & 12 & 31 & 37 & 312 & 390 & 1.897 & 3.665 & 0.917 \\
\hline June & 12 & 26 & 30 & 240 & 295 & 1.906 & 2.762 & 0.926 \\
\hline July & 12 & 28 & 35 & 245 & 340 & 2.098 & 3.016 & 0.975 \\
\hline August & 12 & 29 & 38 & 285 & 370 & 2.790 & 3.013 & 0.921 \\
\hline September & 12 & 28 & 34 & 225 & 290 & 1.798 & 2.091 & 0.911 \\
\hline October & 12 & 29 & 36 & 320 & 335 & 2.765 & 2.011 & 0.901 \\
\hline November & 12 & 28 & 34 & 295 & 345 & 1.980 & 2.754 & 0.913 \\
\hline December & 12 & 27 & 35 & 210 & 310 & 1.786 & 2.781 & 0.933 \\
\hline Mean \pm SD & & $29.08 \pm 1.97$ & $3541 \pm 2.19$ & $280 \pm 40.79$ & $346.66 \pm 3694$ & $0.39 \pm 1.98$ & $2.81 \pm 043$ & $0.92 \pm 0.01$ \\
\hline
\end{tabular}

Table 3. Month wise condition factor of male and female S. plagiostomus in river Jhelum from Kashmir valley

\begin{tabular}{|l|c|c|}
\hline Months & Male (K) & Female (K) \\
\hline January & $0.935 \pm 0.263$ & $1.021 \pm 0.160$ \\
\hline February & $1.067 \pm 0.084$ & $0.882 \pm 0.229$ \\
\hline March & $0.984 \pm 0.307$ & $0.870 \pm 0.143$ \\
\hline April & $1.034 \pm 0.484$ & $1.086 \pm 0.360$ \\
\hline May & $0.937 \pm 0.248$ & $1.318 \pm 0.151$ \\
\hline June & $1.583 \pm 0.381$ & $1.277 \pm 0.269$ \\
\hline July & $1.257 \pm 0.173$ & $1.149 \pm 0.106$ \\
\hline August & $1.026 \pm 0.186$ & $1.139 \pm 0.261$ \\
\hline September & $0.829 \pm 0.123$ & $1.221 \pm 0.018$ \\
\hline October & $1.054 \pm 0.087$ & $1.164 \pm 0.176$ \\
\hline November & $1.088 \pm 0.234$ & $1.216 \pm 0.271$ \\
\hline December & $1.218 \pm 0.208$ & \\
\hline
\end{tabular}




\section{Discussion}

The Length Weight Relationship of fish has significant importance in studying the growth, gonadal development, general well being of fish population and for comparing life history of fishes ${ }^{24,38,40}$. Fisheries management and research often requires the use of biometric relationships in order to transform data collecting from the field into appropriate indices ${ }^{37}$. Studies on the Length Weight Relation of fishes constitutes an important tool in fishery biology and helps to understand whether variations from the expected weight for the known groups are the indicators of fatness, wellbeing and gonadal development in relation to the environment ${ }^{4,24,50}$.I $\mathrm{n}$ the present study, the ' $\mathrm{b}$ ' value was found higher in females as compared to males. The highest ' $b$ ' value in females of S. plagiostomus implies that the females gain weight at a faster rate in relation to its length. The $b$ value of males indicates negative allometric, which indicates that, the increase in length is not in accordance with increase in weight. Similar results were observed by Dar et al. (2012) in Schizopyge esocinus. Le Cren (1951) had reported that females are heavier than males of the same length probably because of difference in fatness and gonadal development. The slope value of regression line less than ' 3 ' has been reported in Tortor (Malhotra, 1982), Labeo dero (Malhotra and Chauhan, 1984), Labeo dyocheilus (Malhotra, 1985), Cyprinus communis and Ctenopharyngodon idella (Dhanze and Dhanze. 1997) and Rasbora daniconius (Sunil, 2000). According to Ruz Campos, 2010 , the b value ranged from a minimum of 2.863 for reef fin spot (Paraclinus integripinnis) to 3.404 for the fluffy sculpin (Oligocottus snyderi). All the earlier reports are in compliance with the present study in which the b value was very close to isometric value of 3 and this indicates that $S$. plagiostomus in the present study showed an isometric growth. Also it is well known that the functional regression $b$ value represents the body form and is directly related to the weight affected by ecological factors habitat, area, seasonal effects, degree stomach fullness, gonad maturity, sex, health, preservation techniques and differences in the observed length ranges of the captured specimens ${ }^{29,17,18}$ (Ricker, 1973. Several workers reported positive allometric growth in freshwater fish; notable among them are $20,34,23,9,19,45,30,42,35$ in Cirrhina mrigala, Catla catla, Labeo bata, Labeo rohita, Pristolepis fasciata, Pangasius pangsius, Pseudorasbora parva and Macrognathus aculeatus respectively. The greater value of ' $b$ ' mainly depends on shape and fatness of individuals of fish. Isometric growth was also reported by (Haniffa et al., 2006; Serajuddin et al., 2013; Kashyap et al., 2015) in Channa punctatus collected from lentic and lotic water bodies. According to to Copp et al. (2013), the isometric body growth of Barbatula barbatula changes to allometric type when it reaches a certain standard length in order to become an adult. This indicates that body growth type sometimes changes accordingly to their physiology needs. Allen, (1938) have reported that the cube law is applicable only for those species which maintain the form and specific gravity throughout their life, but the shape and the form of fish may change with time, so the Length-weight relationship of most of fish species may deviate the cube law. The value of ' $b$ ' reported by Bhat et al. (2010) for S. labiatus differs from the present study, which is possibly due to several factors such as habitat, number of specimens examined and length ranges and length types used. Qadri and Mir (1980) reported the value of 'b' as 2.4487 for S. plagiostomus from the peripheral water bodies of Dal Lake, where as ${ }^{7}$ have reported the ' $b$ ' value of S. plagiostomus (2.928) for the same fish from Jammu water bodies. Our results are in conformity with the earlier reports of Bhagat and Sunder (1983); Qadri and Mir (1980); Bhat (2010). In general it has been observed that the ' $b$ ' values reported of snow trout species from this part of the world are within the range of 2.5 to 3.5 which are considered as normal ' $b$ ' value as reported by ${ }^{14}$. The $b$ values observed in this study were significantly below 3 which mean that the S. plagiostomus in river Jhelum exhibited negative allometric growth pattern except few months in case of females. Finally, the Length-weight relationships and condition factor presented here will provide useful information for fisheries management and fish population dynamic studies. Therefore, the results of the present study can serve as baseline data for these species and for comparisons with future studies.

\section{Acknowledgements}

The author is grateful to the Head, Department of Zoology, University of Kashmir, Hazratbal, Srinagar, India for providing the laboratory facilities and gratefully acknowledge the finincal support from the Department of Biotechnology (DBT), Govt of India, New Delhi on Fish Nutrition and Diet development program. Thanks are also due to Mr. Mufti Buhran, University Chief Executive Engineer for helping the construction of new Feed Technology Laboratory (Wet-Lab.) in the Department of Zoology.

\section{Reference}

1. Achakzai WM, Saddozai S, Baloch WA,Memon N. Length-weight Relationships and condition factor of Oreochromis mossambicus (Peters, 1852) from Manchar lake Distt. Jamshoro, Sindh, Pakistan. Sindh University Research Journal-SURJ Science Series. 2013; 45:201-6.

2. Ahmed KK, Saha SB. Length-weight Relationships of major carps in Kapati Lake, Bangladesh. Naga ICLARM Q. 1996; 19:28.

3. Ali S, Barat A, Kumar P, Sati J, Kumar R, Haldar RS. Study of the Length-weight Relationship and condition factor for the Golden Mahseer, Tor putitora from Himalayan rivers of India. Journal of Environmental Biology. 2014; 35:225-8.

4. Allen K. R. Some observation on the biology of the trout (Salmo trutta) in Windermere. Journal of Animal Ecology. 1938; 7:333-349.

5. Bagenal TB, Braum E. Eggs and early life history. Methods for assessment of fish production in freshwaters, Bagenal TB. ed. IBP (International Biological Program) Handbook. 1978; 3:165-201. 
6. Bagenal TB, Tesch FW. Age and growth. Bagenal, T. Ed. Methods of Assessment of fish Production in fresh waters. Oxford Blackwell Scientific Publication. 1978. p. 101-36.

7. Beyer JE. On Length-weight Relationships: Part II. Computing mean weights from length statistics. Fish byte. 1991; 9:50-4.

8. Bhagath MJ, Sunder S. A preliminary notes on Length-weight Relationship and condition factor Schizothorax plagiostomus (Heckel, 1883) from Jammu region. Journal of Inland Fisheries Society of India. 1983; 15:73-4.

9. Bhat FA, Yousuf AR, Balkhi MH, Mahdi MD, Shah FA. Lengthweight Relationship and morphometric characteristics of Schizothorax spp. in the river Lidder of Kashmir. Indian Journal of Fisheries., 2010; 57:73-6.

10. Chatterji A. Siddiqui AQ, Khan AA. Length-weight Relationship of a carp, Labeo bata (Ham.). Proceedings of the Indian Academy of Sciences. 1977; 86:189-94.

11. Copp GH, Vladimir K, Hensel K. When do fishes become juveniles? Developments in Environmental Biology of Fishes, 19, Springer Science and Business Media 286. 2013.

12. Dar SA, Najar AM, Balkhi MH, Rather MA, Sharma R. Lengthweight Relationship and relative condition factor of Schizopyge esocinus (Heckel, 1838) from Jhelum river Kashmir. International Journal of Aquatic Science. 2012; 3:29-36.

13. Dhanze R, Dhanze JR. Biology of scale and grass carp, Lengthweight Relationship and growth performance under the agro climate zone of Himachal Pradesh. Indian Journal of Fisheries. 1997; 44:255-63.

14. Fafioye OO, Oluajo OA. . Length-weight Relationships of five fish species in Epelago on Nigeria. African Journal Biotechnology. 2005; 4:749-51. https://doi.org/10.5897/AJB2005.000-3136.

15. Froese R. Cube law, condition factor and weight-length relationship: History, meta-analysis and recommendations. Journal of Applied Ichthyology. 2006; 22:241-53. https://doi.org/10.1111/ j.1439-0426.2006.00805.x.

16. Fulton TW. The rate of growth of fishes. Twenty-second Annual Report Part III. Fisheries Board of Scotland, Edinburgh.1904; 3:141-241.

17. Haniffa MA, Nagarajan M, Gopalakrishnan A. Length-weight Relationships of Channa punctata (Bloch, 1793) from Western Ghats rivers of Tamil Nadu. Journal of Applied Ichthyology. 2006; 22:308-9. https://doi.org/10.1111/j.1439-0426.2006.00779.x.

18. Hossain MY, Rahman MM, Fulanda B, Jewel MAS, Ahmed F, Ohtomi J. Length-weight and length-length Relationships of five threatened fish species from the Jamuna (Brahmaputra river tributary) river, northern Bangladesh. Journal of Applied Ichthyology. 2012; 28:275-7. https://doi.org/10.1111/j.14390426.2011.01900.x.

19. Hossain, MY, Sayed SRM, Mosaddequr RM, Ali MM, Hossen MA, Elgorban AM, Ohtomi J. Length-weight Relationships of nine fish species from the Tetulia river, southern Bangladesh.
Journal of Applied Ichthyology. 2015; 31:967-9. https://doi. org/10.1111/jai.12823.

20. Iqbal MJ, Kumar SU, Prakash GO, Kumar DA. Lengthweight Relationships of the India Major Carp, Labeo rohita (Cypriniformes: Cyprinidae) from six drainages of Ganga basin, India. Cuadernos de Investigacion. 2015; 7:71-8. https://doi.org/10.22458/urj.v7i1.864.

21. Jhingran VG. Studies on the age and growth of Cirrhina mrigala (Ham.) from the river Ganga. Proceeding of National Institute of Sciences, India. 1959; 52:107-37.

22. Jobling M. Environmental factors and rates of development and growth. Handbook of Fish Biology and Fisheries, 1. Hart, P.J.B, and Reynolds, J.D. Eds. Blackwell Publishing; 2002. p: 107-9. https://doi.org/10.1002/9780470693803.ch5.

23. Kashyap A, Awasthi M, Arshad M, Serajuddin M. Length-weight, length-length Relationship and condition factor of freshwater murrel, Channa punctatus from Northern and Eastern regions of India. World Journal of Fish and Marine Sciences. 2015; 7:164-70.

24. Khan RA. Studies on the biology of some important major carps. [Unpublished Ph. D. Thesis], Aligarh Muslim University. 1972.

25. Le Cren ED. The Length-weight Relationship and seasonal cycle in gonad weight and condition in the pearch (Perca fluviatilis). Journal of Animal Ecology, 1951; 20:201-19. https://doi. org/10.2307/1540.

26. Malhotra SK. Bionomics of the hill stream Cyprinids I. Food, parasites and Length-weight Relationship of Labeodyo chilus. Proceedings of Indian Academy of Science. 1985; 94:377-81. https://doi.org/10.1007/BF03186344.

27. Malhotra SK, Chauhan RS. Bionomics of hill stream Cyprinids IV. Length-weight Relationship of Labeo dero (Ham.) from India. Proceeding of Indian Academy of Science. 1984; 93:411-7. https://doi.org/10.1007/BF03186288.

28. Malhotra SL. Bionomics of hill stream Cyprinids III. Food, parasites and Length-weight Relationship of Garwhal mahaseer, Tor tor (Ham). Proceeding of Indian Academy of Science. 1982; 91:479-85.

29. Mir JI, Shabir R, Mir FA. Length-weight Relationship and condition factor of Schizopyge curvifrons (Heckel, 1838) from river Jhelum, Kashmir, India. World Journal of Fish and Marine Sciences. 2012; 4:325-9.

30. Miranda R, Galicia D, Monks S, Pulido-Flores G. Weight-length Relationships of some native freshwater fishes of Hidalgo. State, Mexico Journal of Applied Ichthyology. 2009; 25:620-1. https:// doi.org/10.1111/j.1439-0426.2009.01319.x.

31. Mortuza G. Length-weight Relationships of twelve fishes from the river Padma near Rajshahi city, Bangladesh. Journal of Fisheries and Aquaculture. 2015; 6:1-2. https://doi.org/10.4172/21503508.10000113.

32. Mortuza MG, Almisned FA. Length-weight Relationships, condition factor and sex-ratio of Nile tilapia, Oreochromis niloticus 
in Wadi Hanifah, Riyadh, Saudi Arabia. Continental Journal of Biological Science. 2013; 6:1-5.

33. Moutopoulos DK, Stergiou KI. Length-weight and length-length Relationships of fish species from the Aegean Sea, Greece. Journal of Applied Ichthyology. 2002; 18:200-3. https://doi.org/10.1046/ j.1439-0426.2002.00281.x.

34. Muchlisin ZA, Musman M, Siti Azizah MN. Length-weight Relationships and condition factors of two threatened fishes, Rasbora tawarensis and Poropuntius tawarensis endemic to Lake Laut Tawar, Aceh Province, Indonesia. Journal of Applied Ichthyology. 2010; 26:949-53. https://doi.org/10.1111/j.1439-0426.2010.01524.x.

35. Natarajan AV, Jhingran AG. On the biology of Catla catla (Ham.) from the river Jamuna. Proceeding of National Institute of Sciences, India. 1963; 298:327-55.

36. Nile Z, Wu H, Wei J, Zhang X, Ma Z. Length-weight relationship and morphological studies in the kashgarian loach Triplophysa yarkandensis (Day, 1877) from the Tarim river, Tarim river basin, North-West China. Indian Journal of Fisheries. 2013; 60: 15-19.

37. Pathak BC, Serajuddin MA. Comparative study of Length-weight Relationship and condition factor of lesser spiny Eel, Macrognathus aculeatus (Bloach) from the different river basins of India. World Journal of Fish and Marine Sciences. 2015; 7:82-6.

38. Pathak BC, Zahid M, Serajuddin M. Length-weight, length-length Relationship of the spiny Eel, Macrognathus pancalus (Hamilton 1822) sampled from Ganges and Brahmaputra river basins, India. Iranian Journal of Fisheries Sciences. 2013; 12:170-82.

39. Patiyal RS, Lal KK, Punia P, Singh AK, Mir JI. Length-weight Relationship and condition factor of five wild freshwater fish species from river Ganga in India. Journal of Eco Physiology and Occupational Health. 2013; 3:7-11.

40. Pauly D. Some simple methods for the assessment of tropical fish stocks. FAO. Fisheries Technology. FAO, Rome; 1983. p. 234

41. Pervin MR, Mortuza MG. Notes on Length-weight Relationship and condition factor of fresh water fish, Labeo boga (Hamilton) (Cypriiformes: Cyprinidae). Journal Zoology Rajshahi University. 2008; 27:97-8.

42. Petrakis G, Stergious KI. Weight-length Relationship for 33 fish species in Greek waters. Fish Research. 1995; 21:465-9. https:// doi.org/10.1016/0165-7836(94)00294-7.

43. Qadri MY, Yousuf AR. Influence of physico-chemical factors on the seasonality of cladocera in lake Manasbal. Geobios. 1980; 7:273-6.

44. Radkhah A, Eagderi S. Length-weight and length-length Relationships and condition factor of six cyprinid fish species of Zarrineh river (Urmia Lake basin, Iran). Iranian Journal of Ichthyology. 2015; 2:61-4.

45. Ricker WE. Linear regressions in fishery research. Fisheries Research Board of Canada. 1973; 30: 409-439.
46. Ruiz-Campos G, Ramirez-Valdez A, Gonzalez S, GonzalezAcosta AF, Acosta Zamorano D. Length-weight and length-length relationship for nine rocky tidal pool fishes along the pacific coast of the Baja california Peninsula, Mexico. Journal of Applied Ichthyology. 2010; 26: 118-119.

47. Sarkar S, Pressey RL, Faith DP, Margules CR, Fuller T, Stoms DM, Moffett A, Wilson KA, Williams KJ, Williams PH, Andelman S. Biodiversity conservation planning tools: Present status and challenges for the future. Annual Review of Environment and Resources. 2006; 31:123-59. https://doi.org/10.1146/annurev. energy.31.042606.085844.

48. Sarkar UK, Deepak PK, Negi RS. Length-weight Relationship of clown knife fish Chitala chitala (Hamilton 1822) from the river Ganga basin India. Journal of Applied Ichthyology. 2009; 25:2323. https://doi.org/10.1111/j.1439-0426.2008.01206.x.

49. Sekitar PK, Hamid MA, Mansor M, Siti-Azizah MN. Lengthweight Relationship and condition factor of fish populations in Temengor reservoir: Indication of Environmental Health. Sains Malaysiana. 2015; 44:61-6. https://doi.org/10.17576/jsm-20154401-09.

50. Serajuddin M, Prasad L, Pathak BC. Comparative study of Length-weight Relationship of freshwater murrel, Channa punctatus (Bloch1793) from lotic and lentic environments. World Journal of Fish and Marine Sciences. 2013; 5:233-8.

51. Sunil MS. Length-weight Relationship in Rasbora danicnius (Ham.) from Achenkoli river, Pathanamthitta, Kerala, India. Indian Journal of Fisheries. 2000; 47:271-4.

52. Teixeira-de Mello F, Eguren G. Prevalence and intensity of blackspot disease in fish community from a subtropical stream (Santa Lucia river basin, Uruguay). Limnetica. 2008; 27:251-8.

53. Teixeira-de Mello F, Iglesias C, Borthagaray AI, Mazzeo N, Vilches J, et al. Onthogenic allometric coefficient changes. Implicances of diet shift and morphometric attributes in Hoplias malabaricus (Bloch) (Characiforme, Erythrinidae). Journal of Fish Biology. 2006; 69:1770-8. https://doi.org/10.1111/j.10958649.2006.01245.x.

54. Yousuf AR, Bhat FA, Mahdi D, Ali S, Ahangar MA. Food and feeding habits of Glyptosternon reticulatum McClelland and Griffth in Torrential streams of Kashmir Himalayas. Journal of Research Development. 2003; 3:124-33.

55. Zhulan N, Wu H, Wei J, Zhang X, Ma Z. Length-weight Relationship and morphological studies in the kashgarian loach Triplophysa yarkandensis (Day, 1877) from the Tarim river, Tarim river basin, North-West China. Indian Journal of Fishes. 2013; 60:15-9 